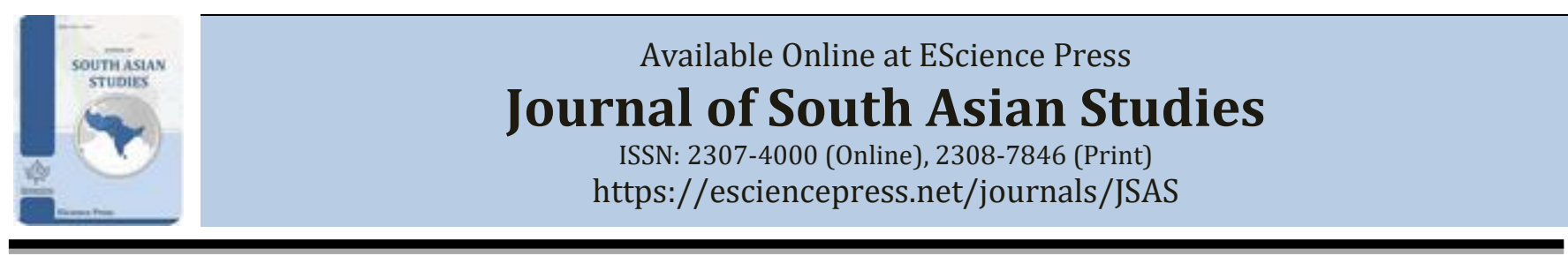

\title{
THE VEILED VOICE: CAN A READING OF MUHAMMAD IQBAL'S POETICAL RESPONSE TO HIS POLITICAL MOMENT IN RELATION TO W. B. YEATS, ILLUMINATE AND RETHINK OUR UNDERSTANDING OF THE SELF AND ITS RELATIONSHIP TO THE NATION STATE?
}

\author{
Saaleh Patel \\ Arts, Languages \& Cultures, Postcolonial Studies, University of Manchester, England, UK. \\ *Corresponding Author Email ID: saaleh.patel23@hotmail.co.uk
}

\section{A B S T RAC T}

\begin{abstract}
Most Western literary critics will be aware of South Asian writers such as Rabindranath Tagore but may not have necessarily been exposed to the poetry of Muhammad Allama Iqbal (1877-1938), who arguably goes further in his critique of British colonialism. Iqbal occupies a unique moment; born in Sialkot (British India), studied at Cambridge and was a minority Muslim in a majority Hindu nation. His perspective allows him to address issues around nationhood, self-determination of Muslims, British imperialism and fanatical nationalism. His primary concern is awakening the Muslim spirit, shaking off political apathy, encouraging social change and cultivation of human potential through his poetry. This is where I want to contrast Iqbal's genius with that of W. B. Yeats (1865-1939), whose poetry was also profoundly concerned with national identity, religion and emancipation from the British empire. In many ways, Iqbal and Yeats share similar concerns: they both works against the attitudes of the writers of their time and in this sense refuse to be categorized into specific literary movements. They are both occupied in anticolonial agitation and later in life even embark upon political careers. Strangely, they even seem to share paradoxes, both advocating and rejecting forms of nationalism. Yet both writers are strikingly dissimilar too. Formally they could not be more different, Iqbal follows an Urdu and Persian model and its various traditional structures whilst Yeats inherits the English tradition of poetry but deconstructs and refashions it to his unique usage. Iqbal is intensely direct and daringly vocal in his reclamation of the language for his people and unwaveringly critiques national identity and Empire. Yeats, in a modernist sense, can be cautious and sometimes evasive. Yeats' romanticizing of a foreign landscape such as India or China, lands us into dangerous territory, for it slips into Orientalist discourse as extensively proliferated by Edward Said. In contrast, Iqbal's aestheticization of his Indian landscape as well as the Hijaz (birthplace of Islam) is a way of reflecting nostalgically on past and then envisioning a new, fresh and hopeful future. Can Iqbal then offer a new way of thinking about the political issues that are so prevalent in our own time nationalism, racism, and a Muslim identity crisis?
\end{abstract}

Keywords: Postcolonialism, nationalism, selfhood, aesthetics, Orientalism.

This paper will construct a unique reading that compares and interrogates the poetry of Muhammad Allama Iqbal (1877-1938) with that of W. B. Yeats (1865-1939). Although a mammoth task, contrasting the two literary giants yields an intriguing exploration of the self, particularly Muslim identity, in relation to nationhood and nationalism. At first glance, though occupying a similar moment of history, the poets seem worlds apart. Iqbal was born in Sialkot, a city still under rule by the British Raj and he was part of a Muslim minority living in a majority Hindu nation. He had received his formal education at Cambridge and then Munich. His upbringing surely informed his views and helped him express issues around the self-determination of Muslims, the dangers of nationalism, the oppression of British imperialism, and in extension the West in his poetry. And at the formal level, Iqbal can be seen as a postcolonial poet because he resisted occidental stylistic 
structures through his refusal to translate his poetry from the Urdu and Persian languages for a western audience. He presents a contrast then, to W. B. Yeats who was an Anglo-Irish poet that inherited the English tradition. Yet he too resisted British imperialism, in his way, by deconstructing and refashioning English language and form. It is striking how one can find so many parallels between both poets' lives and their poetic concerns. They both presented themselves as writers of their time, as writers for their nations, and became a testament of 'Irishness' or 'Muslim Indianness' respectively. They both embarked on political careers later in life too. In terms of their poetry, they were both profoundly preoccupied in an anti-imperial agitation, a worthy concern considering both Ireland and India were colonized by the Crown. Even at the level of literary style, Iqbal and Yeats disturb and evade categorisation: their works transcend labels we ascribe to art, such as Modernist or Romantic. Strangely, they even show a measured taste for the contradictory, both advocating a raw natural love of one's country whilst rejecting other jingoist forms of nationalism. I want to suggest, however, that this is not an inconsistency on their part but rather an organic maturation of thought that occurs with the growth of the poet. The synthesis that I envision in my reading firstly consists of an understanding that poetry and politics are quintessentially connected in Iqbal and Yeats and that poetry and history are mutually dependent on one another. Historical events such as the devastation of The Great War determined the poetry of both poets. But in the same vein, poetry determined history too; such as in the case of Iqbal's political address that envisioned a separate state for Muslims. The creation of Pakistan in 1947 would emerge from Iqbal's inception. In this paper, I will analyze Iqbal's Tul'u-e-Islam (The Resurgence of Islam) alongside a range of both early and late poetry from Yeats; including poems such as The Valley of the Black Pig and Byzantium. Although Iqbal's style differs to Yeats' style in that it is intensely direct, daringly vocal and unwavering in its critique, I want to consider how both poets critique nationalism and nationhood and how an ambivalence begins to emerge when we take a look at both poets' larger oeuvre. I then intend to explore how they consider the human subject in their poetry, how they envision the nature of the self and whether its relationship to the nation state is fundamentally dependent, frictional or both. This paper will culminate in the idea that in the self's struggle to resist and redefine itself against the nation state, both poets attempt to then transcend this dynamic relationship and consider whether through this process a greater potential for the self can emerge or not.

\section{Aestheticization of a Landscape}

I want to begin by assessing both poets' aestheticization of a landscape in their poetry and what potentially ideological concerns can emerge from such an investment. Does such a rendering of the landscape, for example, contribute to discourses of exoticization? I ground my reading of Iqbal's Tul'u-e-Islam and Yeats' Sailing to Byzantium in conjunction with Edward Said's Orientalism. I, however, wish to also disturb the perceived notion that the Orientalizing by the western poet is representative of political incentive, and not simply artistic naïveté. It is clear that both Iqbal and Yeats foreground their poetry in a particular landscape, though for different means. If we read Yeats' Sailing to Byzantium through a postcolonial lens, it seems that to an extent Said's accusation holds weight. The accusation that the configuration of the Orient by the western writer participates in the 'formidable structure of cultural domination' by the Occident; that this relationship dynamic is one of power, that it is a political discourse that continues to, in albeit a more subtle and sinister way, appropriate the Orient and as a result help to ideologically re-define the Occident (Said, 1979: 24). Let us consider how Yeats' speaker begins, 'That is no country for old men. The young / In one another arms, birds in the trees' (Yeats, 2008: 163). Immediately, the early declarative is qualified into a natural landscape. The speaker suggests that Byzantium is a space for youthful autonomy, and it conjures up connotations that come along with its youthfulness such as innocence, skepticism, freedom. He feels agonized by the realization of the coming of old age. Byzantium carries a 'sensual music' and 'monuments of unageing intellect' (Yeats, 2008: 7-8). The speaker exoticizes and imposes upon Byzantium (the East) the trope of sensuality, seductiveness and passion that had been widely prevalent in western Romantic literature. Interestingly, the speaker seems to also suggest, through 'unageing', that Byzantium and in extension the Orient is a dormant and static space. For Said, this has a very clear ideological implication, 'The idea of regenerating a fundamentally lifeless Asia' (Said, 1979: 154). By presenting the East so, as lifeless and static, it provides 
the justification for the colonial mission by the Europeans in order that they may then revitalize such a space. When we consider all of this, Sailing to Byzantium is not just a poem that uses the oriental landscape to contemplate ideas of lost youth, growing old and the nature of art, but it also participates in Orientalist discourse. But to see this poem in only this light takes away its poignancy, its beauty, its meaning. It also seems perplexing that Yeats would impose, as Said explains, an Orientalist discourse when he was indeed an anticolonial poet, one against Empire. He even translated the poetry of Indian literary giants like Rabindranath Tagore into English. Ramazani recognizes Yeats' ability to evade categorization, 'he has often been defined by association with a more general company, be it liberals or fascists, the romantics or the moderns' (Ramazani, 2001: 21). This claim recognizes the ambivalence found in Yeats and registers his precarious position as a white Irish male poet and British colonial subject. It is this precise hybridity that, for Ramazani, makes him one who occupies a 'liminal' space. Yeats remains as always poignantly paradoxical. I am inclined to the notion that Sailing to Byzantium is so much more than an Orientalizing discourse; it is an exploration of the ageing self and what relationship art has in its capture, even if it must be perceived at the holy city of Byzantium. I would like to suggest that this turning towards an oriental landscape may reflect a modernist concern in fact. Let us consider Yeats' fascination with Byzantium. Is it a coincidence that he chooses this particular historically rich holy city; a city that, at the time he was writing was the centre of the Islamic Ottoman Caliphate rule? Does the East present to the western poet a space that contains something that is fundamentally lost within the Occident? Once we contextualize the historical moment; a moment marred by the destruction of The Great War, the lasting effects of imperialism, post-Enlightenment pessimism, the breakdown of objective truths and the monotonous, isolating, dislocating, damaging effects modernity had upon the self, it may be no wonder why the western poet reaches towards the East. This turning towards an eastern landscape becomes a moment of reflection for the self. Just like the iconic last line of T. S. Eliot's modernist pièce de résistance, The Wasteland, 'Shantih shantih shantih' becomes a moment where the speaker seeks to escape the self's damaged sensibility in a ruined societal infrastructure and look beyond to a more natural, spiritual space (Eliot, 2015: 66). For Said, 'it was Indian culture and religion that could defeat the materialism and mechanism (and republicanism) of Occidental culture' (Eliot, 2015: 115). The aesthetics of Yeats' landscape then are not so much an Orientalizing discourse as they are a space for him to revitalize ideas of the self. Indeed this exploration occurs in Iqbal too.

Like Yeats, Iqbal in his poem Tul'u-e-Islam aestheticizes a garden and situates the speaker in a natural landscape. This landscape is not a foreign space, however, and like the first-generation Romantics such as Wordsworth and Coleridge, the aestheticization becomes a space for reflection upon the self and the past. I am not however suggesting that Iqbal's aestheticization of the landscape mirrors a Romantic form of escapism from the poet's particular historical moment either. It instead, metaphorically, uses the garden landscape as a way of navigating a nostalgic past and then envisioning a rebirth, a renewal, a renaissance that ties us back to the content and title of the poem, Tul'u-e-Islam (The Resurgence of Islam)

\section{Form in Iqbal}

I want to now briefly contextualize the form of Iqbal's Tul'u-e-Islam and suggest that its very features reflect the wholeness and totality its content envisions for the self. It is important to clarify that the Iqbal poem I analyze exists as a translation and we must consider whether one loses something elemental in such a language exchange. Von Flotow and Shread explain, 'a translation can never be anything but an excess of the original, even as a yearning for symbiotic oneness hovers on the horizon as an unrealizable dream' (Von Flotow \& Shread, 2014: 593). Here, they astutely recognize the impossibility of fidelity in translation as either the form of the translation is sacrificed for the faithfulness of meaning or the meaning for formal accuracy. Nonetheless, this online translation appears as true as it can be to its Urdu counterpart. Tul'u-e-Islam consists of nine sixteen-line stanzas and the large poem, to the western observer, may seem to meander and even appear ad hoc in its approach to the subject matter. This style, however, is quintessentially Indian (belonging, that is, to an Indo-Muslim tradition). It resembles loosely the Ghazal form, a poem where the stanzas consist of up to fifteen couplets and are able to exist autonomously on their own whilst tightly dealing with a range of content. Indeed, when poems such as Tul'u-e-Islam are performed by singers to live audiences, the performers often restructure the order of the stanzas, incorporate 
stanzas from other poems whilst removing entire stanzas too. Yet from the way in which the stanzas are self-contained, the performers are still able to capture the overall 'spirit' of the poem. Schimmel explains that the Indian subcontinent favors the 'peculiar art' of reciting poetry and that 'a single well-said line can raise a large audience simply up to ecstasy' (Schimmel, 1963: 66). This illustrates that Iqbal's poem is as much an oral form as it is a literary one and we must consider this further dimension. The fact that Iqbal, in one poem, moves from reflecting upon the human self to critiquing Western imperialism and capitalism only to then return to love and hope at the end is neither an accident of form nor a meandering process of thought. It is a reflection upon the complexities and various components that constitute life. Though the stanzas exist as separate entities, they mirror the often contradictory, ambivalent and even paradoxical nature of human life and come together to emerge into one poignant harmony and totality as a poem. The Urdu rhyme structures, the stanzaic form, the journey in which subject matter organically moves to a climactic ending brings these complexities to life.

\section{A Doubling Vision of Nationalism}

Having established the formal structure of Iqbal's Tul'ue-Islam, let us consider how it and Yeats' The Valley of the Black Pig interrogate nationalism and what contradictory elements begin to emerge when we consider both poets' larger oeuvre. Working his way through a nostalgic past and the current historical condition, Iqbal's speaker arrives at an epiphanic moment in the fourth stanza. The translation reads, 'Break the idols of colour and blood and become lost in the community / Let neither Turanians, Iranians nor Afghan remain' (Iqbal, 2011: ll. 51-52). The imperatives become a symbolic parallel of the first Muslims in Makkah, who purged the various forms of polytheism to usher in a new dawn of monotheism. Considering the title of this poem, The Resurgence of Islam, these lines seek to usher a new dawn for Muslims, and in extension for humanity. We must recognize and eliminate the artificial borders of nations. This idea may appear Marxist in its vision but is in fact informed by a belief system of over fourteen hundred years. These lines recognize Islam's doctrine of Ummah or a universal community. The speaker returns to this idea, reiterating in stanza seven, 'Your wings and your plumage are soiled with the dust of colour and race; / You, my bird of the holy shrine, shake your wings before you start to fly' (Iqbal, 2011: 1l. 103-4). The metaphor and vivid imagery capture here the speaker's hope of humanity reaching its fullest potential once the Muslims recognize there is no difference between the Arab and the Ajam (non-Arab). The direct address and speech-like rhythms of the translation mirror the original Urdu, though the Urdu text consists of rhyme too, which gives the lines a further dimension of totality. We can see from these lines then that Iqbal sees nationality as dangerously restraining. $\mathrm{He}$ expounds upon this in his Reflections, 'So long as this so called democracy, this accursed nationalism [...] so long as distinctions of race, colour and geographical nationalities are not wiped out completely, they will never be able to lead a happy and contented life' (Vahid, 1992: 375). The Great War, for Iqbal, was founded upon a despotic nationalism and caused the destruction of millions of lives and his speaker seeks to warn against investing in such emotional patriotism. From these lines and Iqbal's Reflections, we can clearly recognize his distaste for these strains of nationalism, and this is paralleled in Yeats too.

The speaker in Yeats' The Valley of the Black Pig struggles to see the benefits of nationalism upon the individual and society. The undiscriminating havoc that war causes make the speaker lament upon the 'unknown perishing armies' and the sons of Ireland that have gone forever (1.4). Unlike Tul'u-e-Islam, this poem carries an air of exasperation and forlornness throughout. In an intensely direct moment of critique at the British empire and empires across the globe, the speaker concedes 'Being weary of the world's empires, bow down to you, / Master of the still stars and of the flaming door' (Iqbal, 2011: 11. 7-8). The caesuras reflect the weariness of the speaker and grant the lines a lethargic rhythm that emerges into a moment of humility and worship before the 'Master'. The process of imperialism that was built upon and strengthened by a relentless nationalism makes Yeats' speaker helpless and turn to the Divine. Yeats, like Iqbal then, sees empire and nationalism as a destructive force that plagues humanity.

The reflections upon nationalism ossified in Tul'u-eIslam and The Valley of the Black Pig become complicated and even contradicted however when we consider both poets' larger oeuvre. If one is to only read Tul'u-e-Islam, one could easily be forgiven for assuming that Iqbal's Islamic principles and personal views mean a total rejection of national identity and patriotism. This 
is, however, simply not true. It was, in fact, Iqbal who penned Tarānah-i-Hindi, more commonly known as Sare Jahan se Accha (Better than the entire World, is our Hindustan) a song made for children, sung in classrooms even today. The lyrics of this patriotic song show a passionate yearning and love for the motherland and the elegiac quality to it contrasts starkly to Tul'u-e-Islam. This presents us with a contradictory notion that is strangely paralleled by Yeats too. Into Ireland in the Coming Times, for example, Yeats' speaker passionately addresses the reader directly, 'Know, that I would account be / True brother of a company / That sang, to sweeten Ireland's wrong' (II. 1-3). The way in which the 'Know' is separated by a pause heightens the speaker's urgency for the reader's attention and reads as an imperative. The rhyme and sibilance of the third line reflect a song-like quality that displays a profoundly patriotic tone as well as seething anger at those who do not consider him to be a 'True brother'. Like Iqbal in Sare Jahan se Accha, Yeats displays a deep love for his country that appears dissimilar to the despondency of The Valley of the Black Pig. Upon this estranging phenomenon, Williams explains, 'Tagore and Yeats were nationalists, but they have been misunderstood because their particular forms of nationalism [...] the nationalism they espoused resembles the "new" cosmopolitanism' (Williams, 2007: 70). I would go further and suggest that this ambivalence of nationalism can be found in Iqbal too and points towards the hybridity of the 'colonial subject'. Consider Iqbal's 1930 Allahabad presidential address, where he advocated the creation of a separate, autonomous Muslim state. This contrasts startlingly to the vision in Tul'u-e-Islam that saw the breakdown of all national borders and identities. How could such a drastic change in thought occur so? One way of deconstructing this phenomenon is to read this contradiction as an example of late style, as alluded to by Said. Said claims of a second type of 'lateness not as harmony and resolution, but as intransigence, difficulty and contradiction' (Said, 2006: 7). Although this is partially true when we consider the disjunction between Iqbal's 1930 address and Tul'u-e-Islam, I want to go further and suggest that this inconsistency is not a contradiction at all but rather an organic process of thought that begins by rejecting all destructive jingoist tendencies seen in the European War. It then matures in a celebration of sincere and productive love for the motherland especially when it is occupied by a foreign force. It climaxes, quite poignantly, in recognition that the current historical condition for Muslims living under British rule whilst being subjected to Hindu marginalization can only be transcended by a radical solution, that is, the creation of a separate state. This nationalist concern was one of Iqbal's contemporaries too, such as Tagore and Gandhi, individuals who dealt extensively with the opposing forces and multifarious components that nationalism consisted of, especially when the debate of The Swadeshi Movement raged on across the Indian subcontinent. ${ }^{1}$ It is only when we contextualize a poet's poems within their larger body of work that a more wholesome vision emerges, though not always a harmonious one. This nationalist ambivalence shows that the poet's entire oeuvre is an organic phenomenon that reflects the oxymoronic complexities of life. Considering the doublings and the contradictory vision of nationalism we get in both Yeats and Iqbal's oeuvre I now wish to turn to what complex relationship ideas of the nation has to live, that is the individual self.

\section{The Organically Complex Relationship Between the} Self and the Nation

The relationship between the nation state and the self seems one that is resistant, that is frictional, but also mutually dependable upon each another and this toing and froing of movement is explored in both Iqbal's Tul'ue-Islam and Yeats' Byzantium. Remarkably, Iqbal's speaker moves from addressing the weight of colour, race and nationality in stanza seven to immediately turn to introspection upon the self. This movement occurs within the same self-contained stanza and is only separated by a line. The speaker recognizes the intensely close relationship between the individual self and ideas of nationhood derived from the nation. Functioning as a moment of advice, the translation reads, 'Immerse yourself in yourself, my forgetful one, this is the secret of life;' (1.105). This line forms the crux of the poem and is absolutely pivotal to its vision of totality. It requires some unpacking because of its allusiveness. First of all, the translation distinguishes between 'yourself' and 'yourself'. It recognizes the importance of the autonomy of the individual subject and his/her own pursuit of desire. The middle clause 'my forgetful one' appears to work in a self-reflexive way because if the self is to

\footnotetext{
1 The Swadeshi Movement was an economic strategy that favored home-grown products and boycotting British products in order to remove the British Empire from power.
} 
totally immerse itself it becomes forgetful of all else and so this line re-enacts the immersion of the self that the speaker wishes to attain. In the untranslated Urdu, the self is known as khudi. Khudicarries a weighty tradition of its own in Indo-Persian Islamic literature and Iqbal inherits it whilst daringly revolutionizing it in his own thought. Historically the self had been associated with selfishness and the greed of the individual and its will was rejected by Iqbal's contemporary Indian and Persian poets. In Sufi mystical thought, for example, the nafsor the self was meant to be suppressed and even annihilated in order that one may ascend to the upper echelons of spirituality. Iqbal however, as in this instance of the poem, appears to overturn the idea of inhibiting the self and rather emphasizes upon the importance of the self's progression. This even subverts mainstream Western understandings of the self; informed by a Platonic ideal of favoring logic and reason over passions and matters of the heart. In fact, Iqbal stresses the importance of khudi throughout his oeuvre, and his life writings become primarily concerned with such a notion. Nix informs us, 'the concept of khudi, the principle of strengthened Muslim ego and power aimed at the restoration of the dignity and identity of all Muslims [...] all of life derives from the powerful expression of the self (khudi)' (Nix, 2015: 211). Interestingly, however, we must also consider how khudiis etymologically close to and resembles Khuda, the name of God in Persian. Indeed, this draws upon the words enshrined in the Qur'an, 'And We have already created man and know what his soul whispers to him, and We are closer to him than [his] jugular vein' (Surah Qaf, 50: 16). Islam comprehends Allah as closer to the self than one is to their own self. Considering this contextual background then, one actually realizes that Iqbal's concept of the self is constantly informed through his Islamic faith and that when the speaker in Tul'u-eIslam urges the self to immerse in itself it is actually qualified to align with the will of God. We arrive, then, at both a celebration of the self that appears to conflict with Iqbal's contemporaries whilst simultaneously adhering to Islamic Sufi thought on the self too. Like the ambivalence found in his attitude towards nationalism, Iqbal displays a similar doublings with this cyclical return in the self's will. It presents us with a paradox too. Although Iqbal stresses the importance of the autonomy of the individual it is only in one's servitude to God and the Sharia (Islamic Law) that the self paradoxically becomes liberated and enlightened. And this emancipation arises when the self resists nationality, nationalism, race and oppressive societal structures. The concept of khudi in Iqbal, as Nix explains, was a way in which he instilled 'a strong will in the character of Muslims in order to oppose British Imperialism' (p. 211). Iqbal's concern with the self is constantly bound up then in relation to the nation and Moosa informs us that 'his writings reveal his own titanic struggles to come to terms with a modern Muslim self and the construction of personhood in the early twentieth century' (Moosa, 2015: 12). In a post-War world where countries were being carved up and borders were redrawn, the effect it had on re-imagining the self in relation to these changes became a tangible one in the poetry of Iqbal. Although the self relies on the nation to define itself it must resist nationality too in order to thrive and this reflects the movement I alluded to earlier. This concern was not just Iqbal's own but Yeats' too and can be seen in his poetry. Yeats explores his vision of the self in his later poem Byzantium showing the process of maturation that I alluded to earlier when considering the phenomenon of Late Style. Having comprehended the complexities of nationality, Yeats then attempts to envision a greater self. Succeeding Sailing to Byzantium, the speaker finally arrives at the holy city and contemplates upon human complexity. He reflects 'All that man is, / All mere complexities, / The fury and the mire of human veins' (Iqbal, 2011: II. 6-8). Unlike Iqbal, the speaker here deconstructs and dislocates the self. The ambiguity arises not only from the oxymoron 'mere complexities' but from the synecdoche 'veins'. It juxtaposes to the totality found in Iqbal's imperative 'Immerse yourself in yourself' and this obfuscation suggests that true human nature might not be able to be captured in art or poetry. Simultaneously though, in a quintessentially Yeatsian way, these lines construct the self too and this abrasive movement shows that there may be more to the human than the reductive repetition of 'All' suggests. But what remains most estranging of all is when the speaker proclaims, 'I hail the superhuman' (1. 15). This vision is qualified and then revised as 'shade' and then 'image', splintering our vision of this ideal and suggesting that there is immortality to this being (l.10). Although this immortality can be imagined on a meta-level when one considers how the poet immortalizes the subject, this image of the superhuman is quite stunning. Moving from contemplating upon the human, the speaker envisions a 
greater being and I believe this could well be an allusion to Nietzsche's Übermensch. In his philosophy, Nietzsche envisions the maximum potential for human beings by transcending our morals and understandings of good and evil. In fact, this appears to loosely mirror Iqbal's own concept of khudi and the idea of Insan-e-kamil (Perfect Man). Diagne explains, 'the idea that the human being has to achieve his or her destination by becoming the fully accomplished human, the insankamilor homo perfectus, in whom, as a consequence, the divine attributes will be realized' (Diagne, 2015: 34-5).

Interestingly, in a review of Iqbal's Asrar-i-Khudi, E. M. Forster claimed that 'like other of his contemporaries he has been influenced by Nietzsche', to which Iqbal refuted him, considering he had written the poem twenty years before he had ever read or heard of Nietzsche (Shafique, 2011). The fundamental difference between Nietzsche and Iqbal remains that Iqbal always grounded his poetry and ideas upon his faith in God whilst Nietzsche rejected His existence. Nonetheless, it seems that Yeats' allusion to the 'superhuman' becomes a space where he and Iqbal can meet. Watts explains that in Yeats, 'What matters is that the self should achieve harmony [...] The idea of human development, he suggests, should be the organic whole, the harmonious self' (Watts, 2008: xiii). This fundamental concern with the self and selfimprovement is a concern then for both poets. We must also consider their historical moment and the changes in existential thought that then affected our notions of what constituted the modern self. Both poets attempt to visualize a greater self that reaches prime condition once it recognizes its relation to the nation. In its rejection of despotic forms of nationalism, a resistance is first established, but its celebration of a productive love for nationhood inevitably leads to a mutual dependency between the self and the nation state too. In Iqbal and Yeats, this movement is simultaneous and constantly morphing. Yeats comprehends man as a 'shade' or 'image' and then envisions what he (the self) can become. Iqbal recognizes that self-change must precede social and material change and that the self constitutes itself too. They both recognize that the self is dependent on the nation but that its urge to resist it in their poetry creates this frictional forward-backwards movement.

\section{Departing Visions of Selfhood}

I now explore where the poets appear to depart in their inception of the greater self, particularly when we juxtapose Iqbal's hopeful vision against Yeats' bleaker, often defeatist poetic reality, seen in The Second Coming. This is where Iqbal offers an alternative to western epistemologies, to the Modernist preoccupation with hopelessness. This message has a timeless resonance to it. As established, Iqbal's poem functions as a journey, like that of Shelley's Julian and Maddalo, and addresses the problems the speaker envisions. He laments 'Even now, mankind is the miserable prey to imperialism; / How distressing, that man is hunted by man!' (Iqbal, 2011: 1l. 113-114). This couplet functions as a disconcerting topic shift from the previous stanza's celebration of the nature of the self. It is interesting that the original couplet in Urdu retains the rhyme found throughout the poem and seems to fight against the frustration of the content of these lines. The predatory imagery provides a scathing attack and an overtly direct response to the West, a striking juxtaposition to the indirectness found in Iqbal's Modernist contemporaries. The speaker goes on, 'The glitter of modern civilization dazzles the sight; / But this clever craftsmanship is a mosaic of false jewels' (Iqbal, 2011: 1l. 115-116). The aesthetics of these lines are striking because it chafes against the content. The lines too, draw in the reader with its 'dazzle' and ultimately expose the false idol that is modernity for the speaker. It appears to function on a meta-level; the poet crafts the lines that expose this colorful 'mosaic'. The 'mosaic' being a much older traditional art form and a form inherited by the earlier Muslims contrasts starkly to the 'modern civilization' the lines seek to reject, a largely Western construction. This idea was not unheard of in the Indian annals of literature either; it appears to reject a reconciliatory or organic vision of India that modernizes itself along with the West as envisioned by Tagore. These lines follow instead a Gandhian sensibility that rejects Western modernity and favors self-autonomy through labor and oriental epistemologies that would spiritually benefit the Eastern subject. The speaker's rejection of the materialism that, he sees, has blinded the West is informed by an Islamic sensibility and it also, in some way, surprisingly registers Engels' secular pronouncement that 'Money is the god of this world' (Engels, 2009: 115). The speaker recognizes that 'modern civilization' dazzles the self because it is structured around capitalist exploitation and is bereft of any self-worth or spirituality. Instead, the speaker urges the reader to look forward to the future rather paradoxically 'I implore you; renew the law of the past!' (1. 133). Though Iqbal's speaker is critical of 
the West, he does not absolve the Muslims from blame either. Nix explains, 'he suggests in the strongest terms that India's Muslims were at least partially responsible for their condition' (p.202). Moving from the destructiveness of modernity and the oppression of the West on the East, the speaker envisions a change in the condition of the Muslim self through this return to nostalgic greatness, through a rejection of Western influence, through an acceptance of one's own cultural tradition, through self-change, and through love. The speaker urges one to 'become the language of love' (1.100). A hopeful vision materializes from the despair once the self becomes a vessel for love and transcends the artificial labels, binaries and boundaries. The speaker assumes this change can be enacted through his poetry and this idea goes back to the primal notion of the humanizing phenomenon of poetry. Nix demonstrates that in Iqbal 'the essence of khudi is love and that the self is enlivened by its passion. However, the love he described is the believer's love for God and the Prophet, Muhammad' (p.211-222). Loving God also means to love His creation too and so expresses the speaker's vision of universal love. It is clear then, that the speaker's metaphorical journey from despair and lamentation moves to an epiphany that love is ultimately synonymous with the regeneration of the self and it is the force that tears at the differences that the nation state and the self's notions of nationhood seek to create.

In Yeats' The Second Coming one can see that this vision for a self beyond its relationship with the nation, one of a greater self, falls short and is not actualized like that in Iqbal. Clearly, in Yeats' poem, there is a breakdown between history, that is the past as perceived by the speaker, the present and future. This is achieved by the blurring of the tenses throughout the poem. The paradoxes and inversions of established ideas that haunt the poem make for a nightmarish reality. We must consider that this poem was written not long after The Great War, the Easter Rising and the Irish War of Independence. It is no wonder then that the poem remains harrowingly bleak. The speaker cries out, 'The best lack all conviction, while the worst / Are full of passionate intensity' (Iqbal, 2011: II. 7-8). The lamentation certainly mirrors that of Iqbal's speaker on imperialism and registers an oxymoronic reality. It seems that the best should remain the ones full of 'passionate intensity' and the 'worst' of humanity as those lacking 'conviction'. This inversion really compounds the breakdown the speaker envisions of society and displays a hopeless vision. Like Iqbal's speaker, the speaker in The Second Coming witnesses the horror that pervades everywhere, 'Things fall apart; the centre cannot hold; / Mere anarchy is loosed upon the world' (Iqbal, 2011: 1l. 3-4). It is incredible that this line re-enacts the idea that things fall apart, with the caesura shattering the stability of the line. These iconic lines totally disrupt the perceived subjectivity of the speaker, and like Eliot's The Wasteland, capture despairing hopelessness. Having witnessed the horrors, the speaker then bursts forth in a prophetic-like declaration 'Surely the Second Coming is at hand. / The Second Coming!' (Il. 10-1). It is fascinating that through the changing of the repetition, the declarative becoming an exclamatory and the entire tone shifts drastically. The line moves from a limp, lethargic and exasperating tone to apostrophic drama. In despair, the speaker turns towards divine intervention and seeks the Second Coming of Christ as a symbol to bring back peace and an end to suffering. But in a very Yeatsian way, one cannot simply pin down this meaning as an allusion to the Biblical Second Coming. The obfuscation that arises with the sight of the Sphinx later inverts this idea and suggests that this Second Coming may not be Christ at all. In a last moment of hedging, the speaker asks, 'And what rough beast, its hour come around at last, / Slouches towards Bethlehem to be born?' (Iqbal, 2011: 1l. 21-2). It is hard to actualize that the 'rough beast' could ever be Christ and makes one consider an alternative vision. The vision climaxes in these last lines as we once again arrive at a distorted reality. It is the penultimate line that ends with 'last' but the final line that ends with birth. Not only does this suggest a cyclical space in which this despair remains unending, but a moment that does not, quite incredibly, await with pleasure the Second Coming. Is the speaker then suggesting that though he seeks a moment of divine intervention, it is neither going to occur nor be the one he wishes it to be? For Yeats then, because of the pervasive destruction no betterment for the self can be truly actualized, only 'hailed' at, as in Byzantium. The Second Coming becomes a failed promise for the speaker.

Unlike Iqbal then, Yeats' speaker in The Second Coming cannot foresee or sustain a productively hopeful vision for the self beyond. And this is where Iqbal and his Modernist contemporaries depart. In Tul'u-e-Islam, it is remarkable that such a long poem displays a certain 
totality and unity that is not there in works of art at this particular historical moment. Unlike the cyclical despair envisioned in The Second Coming, Iqbal's cyclical return to a new future displays a consistent alternative. The very first line of the poem sets a metaphorical landscape of things to come, 'The sun has risen over the horizon; / the time of deep slumber has passed' (1. 1). The speaker ties the rising of the sun to a new dawn that urges the Muslims to shake off the apathy and indifference that has plagued them. This is the Resurgence, the Renaissance of the poem's title. And we return to this very idea in the last line, 'Let us split open the roof of the heavens and think upon new ways' (l. 144). The hyperbolic utterance mirrors in its aesthetics a Romantic concern with the natural when we consider 'horizon' and the latter 'heavens'. And it springs forth a hopeful, daring and optimistic new future concerned with a philosophical sensibility, an urge to change the condition of the self through contemplation of the self's relationship to the nation, moving beyond its struggle with it and actualizing it through love. Moosa succinctly explains Iqbal 'was not interested in representing reality; but in the tradition of Karl Marx, he was more interested in changing reality. But, in another sense, Iqbal was also unlike Marx. For him, the deepest revolution he sought began within the self' (p. 20). And this revolution can begin once the self comprehends its complex relationship to the nation and then its struggle to transcend the dynamic. Typical of Iqbal then, his vision remains a poignantly consistent one; always one of hope for the self. Iqbal goes further than his Modernist counterparts in that he offers a poetical solution as opposed to despair. And in this way, he, quite faithfully, embodies Adorno's assertion that 'political falsehood stains the aesthetic form' (Adorno, 1977: 186).

In this paper, I have explored where Iqbal and Yeats' poetry can meet, a concern that up until now has not been explored. It is truly remarkable how both poets appear to mirror similar concerns in their poetry even though they occupied very different worlds. Through my analysis of Iqbal's Tul'u-e-Islam and Yeats' early and late poetry, one can determine how both poets reflect upon and interrogate complex philosophical notions and dynamics. They firstly share a startling ambivalence in their exploration upon nationalism. It begins at a meditation upon the historical moment, a world torn by the catastrophic effects of The Great War. In Yeats and Iqbal, nationalism is interrogated, criticized, pressurized and diminished to a dangerously restraining phenomenon. This notion is then startlingly overturned when we consider both poets' larger oeuvre. Here we find a patriotic love for the nation as seen into Ireland in the Coming Times or in the form of a passionate elegy for the motherland as explored in Tarānah-i-Hindi. In Iqbal, his very conception of breaking the racial and artificial national boundaries is completely reversed with inception that supports the creation of an independent, autonomous Muslim state. This profound ambivalence towards nationhood and nationality reflects their historical moment and their unique positions as 'colonial subjects'. In Yeats and Iqbal, we find a complex formulation of the self in relation to the nation that is both organic and in constant evolution, constantly remolding and refashioning what nationhood is and what influence the nation state has on constructing the self. This dynamic exists, in their poetry, as one where the self seeks to resist the influences of nationalism but that it ultimately relies on it too for its reimagining; for its reconstruction. It creates a relentless forwardbackward movement and struggle between the self and nation state. Iqbal's formulation of khudiin Tul'u-e-Islam envisions what the self can be, what it can aspire to become in its resistance to nationality. In this vein, Yeats' exploration of the 'superhuman' in The Second Coming loosely reflects Iqbal's Insan-e-Kamil, moving beyond this complex relationship and envisioning greater selfhood. In Yeats, however, though there is a promise for this greater self and in extension a better world space, it is never realized and falls short of this vision because of the speaker's inability to look beyond the pervasive destruction that nationhood and nationality have caused. The aesthetics of this landscape become a space for him to view the past, the historical moment and the self's relation to this carnage. In Iqbal we go further; the past is worked and contemplated upon to envision a better future and this vision of a greater self is actualized through a change in attitude, through change in the very condition of the self by an understanding of the force of love and hope. Even the very form in Iqbal's poem, the rhyme, the Ghazal stanzas reflect the wholeness and totality the speaker envisions for the self in relation to the nation and beyond it. And therein lies the genius of Iqbal; to spring forth a pretty lotus from the filthy mud. 


\section{REFERENCES}

Adorno, Theodor W. (1977). 'Commitment'. In Aesthetics and Politics, trans. by Ronald Taylor. London: Whit stable Litho Ltd.

Diagne, S. Bachir. (2015). Achieving Humanity: Convergence between Henri Bergson and Muhammad Iqbal. In Essays on the Reconstruction of Modern Muslim Thought. Edinburgh: Edinburgh University Press.

Eliot, T. S. (2015). Selected Poems. London: Faber \& Faber.

Engels, Friedrich. (2009). The Condition of the Working Class in England. London: Penguin Classics.

Flotow, L. Von, \& Shread, C. (2014). Metramorphosis in Translation: Refiguring the Intimacy of Translation Beyond the Metaphysics of Loss. Signs, 39(3), 592-596.

Iqbal, Muhammad Allama. (2011). Tul'u-e-Islam, Allama Iqbal Poetry. Retrieved from $<$ http://iqbalurdu.blogspot.co.uk/2011/04/bang-e-dra-163-tulu-e-islam.html>

Moosa, E. (2015). The Human Person in Iqbal's Thought. In Essays on the Reconstruction, Edinburgh: Edinburgh University Press, 12-32.

Nix, Dayne E. (2015). Muhammad Iqbal: Restoring Muslim Dignity through Poetry, Philosophy and
Religious Political Action. In Essays on the Reconstruction. Edinburgh: Edinburgh University Press, 201-234.

Ramazani, J. (2001). The Hybrid Muse: Postcolonial Poetry in English. Chicago: University of Chicago

Pres.

Said, Edward W. (1979). Orientalism. New York:

Pantheon Books.

Said, Edward W. (2006). On Late Style. New York:

Pantheon Books.

Schimmel, A. (1963). Gabriel's Wing. Leiden: E. J. Brill.

Shafique, K. Ali. (2011). E. M. Forster on Iqbal's Asrar-i-

Khudi, The Republic of Rumi. Retrieved from

$<$ http://republicofrumi.blogspot.co.uk/2011/11/

e-m-forster-on-iqbals-asrar-i-khudi.html>

Vahid, S. A. (1992) Thoughts and Reflections of Iqbal.

Lahore: Kazi Publication.

Watts, C. (2008). Introduction. In the Collected Poems of

W. B. Yeats. London: Wordsworth Edition.

Williams, L. B. (2007). Overcoming the "Contagion of Mimicry": The Cosmopolitan Nationalism and Modernist History of Rabindranath Tagore and W. B. Yeats'. The American Historical Review, 112(1). Yeats, W. B. (2008). The Collected Poems of W. B. Yeats. London: Wordsworth Editions.

Publisher's note: EScience Press remains neutral with regard to jurisdictional claims in published maps and institutional affiliations.

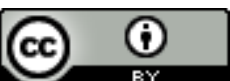

Open Access This article is licensed under a Creative Commons Attribution 4.0 International License, which permits use, sharing, adaptation, distribution and reproduction in any medium or format, as long as you give appropriate credit to the original author(s) and the source, provide a link to the Creative Commons license and indicate if changes were made. The images or other third-party material in this article are included in the article's Creative Commons license, unless indicated otherwise in a credit line to the material. If material is not included in the article's Creative Commons license and your intended use is not permitted by statutory regulation or exceeds the permitted use, you will need to obtain permission directly from the copyright holder. To view a copy of this license, visit http://creativecommons.org/licenses/by/4.0/.

(C) The Author(s) 2019. 